\title{
Energy performance assessment and optimization of extensive green roofs in different climate zones of China
}

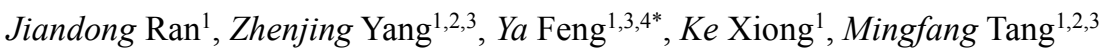 \\ ${ }^{1}$ School of Architecture and Urban Planning Chongqing University, Chongqing 400044, PR China \\ ${ }^{2}$ Key laboratory of new technology for construction of cities in mountain area, ministry of education, Chongqing University, \\ Chongqing 400044, PR China \\ ${ }^{3}$ Chen Qigao Building Science and Technology Research Center, Chongqing 400044, PR China \\ ${ }^{4}$ China Southwest Architectural Design and Research Institute Corp., Ltd, Chengdu 610041, PR China
}

\begin{abstract}
There are many research and engineering projects on extensive green roofs, however, there is still no design guide for green roofs ' climate energy efficiency, which limits the further promotion and usage of it, especially in China containing five climate zones. Taking different climate zones of China as examples, the verified building model is used in the DesignBuilder software, and 2-4 typical cities in each climate zone are selected, then combined the genetic algorithm (GA-II) to optimize the energy efficiency of the building under green roofs. The results show that in all the cities studied in the five climatic zones, extensive green roofs are more energy efficient than ordinary thermal insulation roofs, and the energy saving rate is between 1-26.4\%; except for the Nenjiang, which the energy is mainly used for heating, the cooling energy consumption is reduced and the heating energy consumption is increased after the optimized green roof is adopted in other cities; it is also found that the energy saving rate of the green roof with optimization has a high correlation with the total annual solar radiation value of the city. In addition, the energy efficiency optimization of green roofs in all cities shows that a larger leaf area index is more conducive to energy conservation; however, in southern China, it is not recommended to use a thermal insulation layer in the roof structural layer below the soil.
\end{abstract}

\section{Introduction}

The building sector currently accounts about $30-40 \%$ of the world primary energy, which is responsible for onethird of greenhouse gas emissions (responsible for global warming) around the world. In buildings, most energy consumption is used for heating and cooling applications. It is estimated that $10-20 \%$ of this energy is used by HVAC equipments[1]. Global concern of the environ-mental impacts of the fossil fuel usage has prompted the interest to search and use passive techniques for heating and cooling of the buildings[2], one of the most important solution is green roofs.

Green roofs has several definitions stemmed from various viewpoints during the process of applying. For example, green roofs is not only called eco-roofs because of their ecological benefits[3] but also called roof gardens or living roofs by other professionals[4]. Green roofs strategy is sustainable roof design. Research and practice results have shown many advantages of green roofs which is included reducing urban heat-island effect, reducing stormwater runoff, enriching biodiversity, and cleaning runoff and air. In addition, it saves energy for cooling and heating spaces because of its thermal insulation, resulting in improved energy efficiency of buildings[5].

In the study of energy performance of green roofs, Sailor[6] analyzed the influence of roofs design on building energy consumption in four distinct which represented different climate conditions in the United States. It was found that different outdoor meteorological conditions require different buildings and insulation plans for green roofs. In addition, the simulation in Chicago showed the sensitivity of green roofs design in winter while that in Houston showed it was more sensitive in summer, which proved that the influence depended largely on the building location (climate) [7].

In warm climates, an opaque and common roof surfaces will absorb heat and then distribute it into indoor and outdoor environment, leading to the increasingly consumption of temperature regulation of indoor environment. However, in cool climates, green roofs will help reduce heat flux through the roof surface of the building. Then it will isolate and reduce the potential energy cost of heating the interior space. These benefits are enhanced when snow covers the plant substrate in winter, leading to higher thermal resistance values, but it also has pointed out that net thermal benefits of green roofs in winter would depend on

\footnotetext{
* Corresponding author: fc10@xnjz.com
} 
climate, plant choice, roof construction and location[8]. Jaffal et al. [9] suggested the total energy of green roofs reduced by $32 \%$ under the Mediterranean climate, $6 \%$ in moderate climate and $8 \%$ in cold climate. And they stressed that the effectiveness of green roofs depends largely on the climate. It was more effective to improve thermal comfort and reduce cooling demand, especially in hot zone. What's more, a significant reduction in heating demand can also be found in cold zone.

Although extensive studies have shown that green roofs can improve energy efficiency, researchers still find that they also have a negative impact on energy performance $[10,11]$ because their research on climate is inconsistent. Therefore, it is necessary to make further study on the applicability of green roofs under different climatic conditions. China has a vast territory, which can be divided into five climatic zones from north to south. These climatic zones show a significant difference in solar radiation, air temperature, humidity, wind speed and other outdoor weather conditions. However, most green roof studies in China have considered their applicability and applications in single or several cities, such as Chongqing, Guangzhou and Beijing [12]. This also leaded to the fact that China's current green roofs design guidance still did not cover climate and energy efficiency, which blocked the further promotion of green roofs. Comparing roof greening performance in different climatic zones will help to adjust roof greening settings in cities across China and similar weather conditions.

In addition to location and climate, another possible negative impact of green roofs on energy performance is heat removal at night. The experimental investigation of a light roof in Shanghai by $\mathrm{He}[13]$ showed that the indoor air temperature was about $2.5^{\circ} \mathrm{C}$ higher for green roofs than common roof at night when the doors and windows of both rooms were locked. An experiment by Bevilacqua[14] suggested that, in summer, the additional thermal resistance of the green layers limits the night heat exchange of the indoor environment toward the outdoors through the roof surface, especially in the case of high-insulated buildings, generating a higher temperature of the bottommost layers and impeding the night cooling of the interior spaces. This can consequently result in an increased energy load for cooling in the summer season.

Therefore, the combination of green roofs and night ventilation seems to be a better solution. An experiment in summer by Roche and Berardi[15] showed that the combination of green roofs as thermal mass and night ventilation was benefit for indoor thermal environment. Jiang[12] et al. used the energy simulation by EnergyPlus software, which demonstrated that the combination of green roofs and ventilation can save $10.3-24.6 \%$ of cooling energy according to different climate. When night temperature is low, night ventilation can effectively reduce HVAC operation time. And $\operatorname{Ran}[16,17]$ got a similar result as well. Unfortunately, none of the above studies has carried out a deep study on its structure in different climates.

Zeng et al. [18] conducted simulation research on the green roofs of four representative cities in four climatic zones in China, and selected the optimal parameters of plant and soil thickness, but these parameters is only applicable to the selected city. And the possible impact of roof insulation on green roof energy efficiency was also not considered.

Therefore, the aim of this paper is to combine the two passive technologies including night ventilation and green roofs, and to use the DesignBuilder software and the genetic algorithm (GA- II) to optimize the energy saving efficiency of the above technologies in several climates of China, as well as the detailed parameters of green roofs in typical cities in various climates regions. The results will help architects, civil engineers, developers and building stakeholders in different zones to consider the exact parameters of roof greening in their own projects, which is beneficial to the further advancement of building energy conservation in China.

\section{Method}

\subsection{Zones of building thermal design and weather data}

China has a vast territory and a variety of climates. In order to distinguish the impact of climatic conditions on buildings in different regions, and to clarify the basic design requirements for each climate zone, the standard [19] divides China into 7 first-level climate zones.

However, in the early stage or in the process of architectural design, it is often considered the first-level zones of building thermal design, that is, severe cold zone, cold zone, hot summer and cold zone, hot summer and warm winter zone, and moderate climate zone. The main indicator that distinguishes them is the average monthly temperature of the coldest or hottest month. Other factors that may affect the comfort of the occupants in the building or the energy consumption are ignored, especially solar radiation. This would one of the reasons for the low energy efficiency of some buildings designed according to the standards.

Therefore, the use of building simulation is one of the main methods for assessing the energy efficiency of buildings. One of the main reasons is that the weather data used by them considers a variety of factors, such as temperature, solar radiation, wind speed and even precipitation.

The meteorological data source used in this article is CSWD(Chinese Standard Weather Data), which includes hourly ambient temperature and humidity, solar radiation, and wind speed. This meteorological data source is widely used in China.

\subsection{Verification and model introduction}

The comparison is performed through a numerical analysis performed using the DesignBuilder which has a much more user-friendly interface, and it relies on the EnergyPlus simulation engine to perform energy balance calculations and hourly time steps.

In previous work, many researchers have verified its effectiveness for simulating the calculation of green roof 
thermal processes. In addition, we also discussed the verification process in detail in previous work $[12,16]$ and found that the computer simulation program EnergyPlus with Ecoroof and ventilation model perform adequately and is reliable for predicting the thermal performance of a green roof and night ventilation system in the energy saving simulation.

The reference building model is a standard threestory office building. The physical arrangement of the model space is shown in Fig. 1. This model is mostly used to simulate the energy consumption and indoor thermal comfort of office buildings. Its size was $30 \mathrm{~m}$ $(\mathrm{L}) \times 30 \mathrm{~m}(\mathrm{~W}) \times 4.2 \mathrm{~m}(\mathrm{H})$. The model space includes four exterior zones, four interior zones, facing four different directions, a shaft and a corridor in the middle. The width of four exterior zones was $4.5 \mathrm{~m}$ measured from the perimeter, and the width of the corridor is 3.5 $\mathrm{m}$, and the shaft is a square of $5 \mathrm{~m}$.

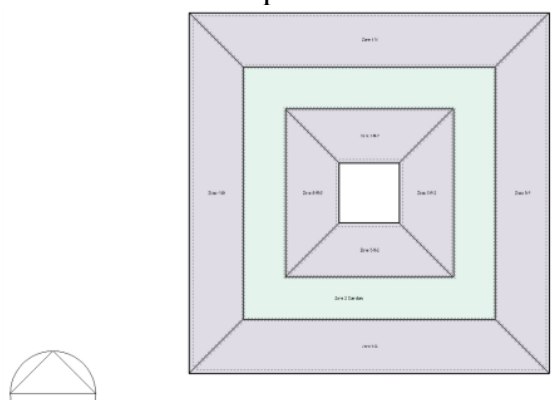

Fig. 1. Zones for a typical floor of the office building.

The model space mainly refers to the Technical standard for nearly zero energy buildings [20]. When it is not specified in this standard, it refers to Design standards for the energy efficiency of public buildings [21], the settings of the model space were as follows:

- The heat transfer coefficient settings of the wall, partition and floor are shown in Table 1;

- The heat transfer coefficient and solar heat gain coefficient (SHGC) settings of the window are shown in Table 1;

- Window to Wall Ratio (WWR): 50\% for all walls;

- Density for occupant: $10 \mathrm{~m}^{2} /$ person;

- The internal thermal gains of lighting and equipment are $9 \mathrm{~W} / \mathrm{m}^{2}$ and $15 \mathrm{~W} / \mathrm{m}^{2}$, respectively, and the hourly usage rate is set according to the standard [20];

- Fresh air requirement: $30 \mathrm{~m}^{3} /(\mathrm{h} \cdot$ person);

- Occupation schedule: 8:00 am to 5:00 pm on weekdays, used for lighting, equipment, and people, the room hourly personnel presence rate is set according to standard [20].

- Ventilation schedule: 9:00 pm to 7:00 am on weekdays. It is worth noting that to optimize the ventilation effect, the ventilation control method is temperature control, that is, in summer, when the indoor temperature is higher than outdoors, ventilation is performed.

- Equipment operation schedule: 8:00 am to 6:00 pm on weekdays, the cooling set point temperature is $26{ }^{\circ} \mathrm{C}$ in summer, and the heating set point temperature is $20{ }^{\circ} \mathrm{C}$ in winter.
Table 1. Envelope performance parameters

\begin{tabular}{|c|c|c|c|}
\hline $\begin{array}{c}\text { Climatic } \\
\text { zone }\end{array}$ & City & Envelope & $\begin{array}{c}\text { Performance } \\
\text { parameters }\end{array}$ \\
\hline \multirow{5}{*}{$\begin{array}{l}\text { Severe } \\
\text { cold zone }\end{array}$} & \multirow{5}{*}{$\begin{array}{l}\text { Urumqi, } \\
\text { Nenjiang, } \\
\text { Golmud, } \\
\text { Shenyang }\end{array}$} & $\begin{array}{l}\text { External } \\
\text { wall }\end{array}$ & $\mathrm{K}=0.25 \mathrm{~W} /\left(\mathrm{m}^{2} \cdot \mathrm{K}\right)$ \\
\hline & & Roof & $\mathrm{K}=0.2 \mathrm{~W} /\left(\mathrm{m}^{2} \cdot \mathrm{K}\right)$ \\
\hline & & Window & $\begin{array}{c}\mathrm{K}=1.2 \mathrm{~W} /\left(\mathrm{m}^{2} \cdot \mathrm{K}\right) \\
\mathrm{SHGC}=0.4\end{array}$ \\
\hline & & Floor & $\mathrm{K}=0.3 \mathrm{~W} /\left(\mathrm{m}^{2} \cdot \mathrm{K}\right)$ \\
\hline & & $\begin{array}{c}\text { Partition } \\
\text { wall }\end{array}$ & $\mathrm{K}=1.2 \mathrm{~W} /\left(\mathrm{m}^{2} \cdot \mathrm{K}\right)$ \\
\hline \multirow{5}{*}{$\begin{array}{l}\text { Cold } \\
\text { zone }\end{array}$} & \multirow{5}{*}{$\begin{array}{l}\text { Beijing, } \\
\text { Hotan, } \\
\text { Lhasa, } \\
\text { Xi'an }\end{array}$} & $\begin{array}{c}\text { External } \\
\text { wall }\end{array}$ & $\mathrm{K}=0.3 \mathrm{~W} /\left(\mathrm{m}^{2} \cdot \mathrm{K}\right)$ \\
\hline & & Roof & $\mathrm{K}=0.3 \mathrm{~W} /\left(\mathrm{m}^{2} \cdot \mathrm{K}\right)$ \\
\hline & & Window & $\begin{array}{c}\mathrm{K}=1.5 \mathrm{~W} /\left(\mathrm{m}^{2} \cdot \mathrm{K}\right) \\
\mathrm{SHGC}=0.4\end{array}$ \\
\hline & & Floor & $\mathrm{K}=0.5 \mathrm{~W} /\left(\mathrm{m}^{2} \cdot \mathrm{K}\right)$ \\
\hline & & $\begin{array}{c}\text { Partition } \\
\text { wall }\end{array}$ & $\mathrm{K}=1.5 \mathrm{~W} /\left(\mathrm{m}^{2} \cdot \mathrm{K}\right)$ \\
\hline \multirow{5}{*}{$\begin{array}{c}\text { Hot } \\
\text { summer } \\
\text { and cold } \\
\text { winter } \\
\text { zone }\end{array}$} & \multirow{5}{*}{$\begin{array}{l}\text { Shanghai, } \\
\text { Guilin, } \\
\text { Chongqing }\end{array}$} & $\begin{array}{c}\text { External } \\
\text { wall }\end{array}$ & $\mathrm{K}=0.4 \mathrm{~W} /\left(\mathrm{m}^{2} \cdot \mathrm{K}\right)$ \\
\hline & & Roof & $\mathrm{K}=0.35 \mathrm{~W} /\left(\mathrm{m}^{2} \cdot \mathrm{K}\right)$ \\
\hline & & Window & $\begin{array}{c}\mathrm{K}=2.2 \mathrm{~W} /\left(\mathrm{m}^{2} \cdot \mathrm{K}\right) \\
\mathrm{SHGC}=0.27\end{array}$ \\
\hline & & Floor & none \\
\hline & & $\begin{array}{c}\text { Partition } \\
\text { wall }\end{array}$ & none \\
\hline \multirow{5}{*}{$\begin{array}{c}\text { Hot } \\
\text { summer } \\
\text { and warm } \\
\text { winter } \\
\text { zone }\end{array}$} & \multirow{5}{*}{$\begin{array}{l}\text { Nanning, } \\
\text { Haikou, } \\
\text { Fuzhou }\end{array}$} & $\begin{array}{c}\text { External } \\
\text { wall }\end{array}$ & $\mathrm{K}=0.8 \mathrm{~W} /\left(\mathrm{m}^{2} \cdot \mathrm{K}\right)$ \\
\hline & & Roof & $\mathrm{K}=0.6 \mathrm{~W} /\left(\mathrm{m}^{2} \cdot \mathrm{K}\right)$ \\
\hline & & Window & $\begin{array}{c}\mathrm{K}=2.8 \mathrm{~W} /\left(\mathrm{m}^{2} \cdot \mathrm{K}\right) \\
\mathrm{SHGC}=0.15\end{array}$ \\
\hline & & Floor & none \\
\hline & & $\begin{array}{c}\text { Partition } \\
\text { wall } \\
\end{array}$ & none \\
\hline \multirow{5}{*}{$\begin{array}{l}\text { Moderate } \\
\text { zone }\end{array}$} & \multirow{5}{*}{$\begin{array}{l}\text { Bijie, } \\
\text { Simao }\end{array}$} & $\begin{array}{l}\text { External } \\
\text { wall }\end{array}$ & $\mathrm{K}=0.8 \mathrm{~W} /\left(\mathrm{m}^{2} \cdot \mathrm{K}\right)$ \\
\hline & & Roof & $\mathrm{K}=0.6 \mathrm{~W} /\left(\mathrm{m}^{2} \cdot \mathrm{K}\right)$ \\
\hline & & Window & $\begin{array}{c}\mathrm{K}=2.2 \mathrm{~W} /\left(\mathrm{m}^{2} \cdot \mathrm{K}\right) \\
\mathrm{SHGC}=0.3\end{array}$ \\
\hline & & Floor & none \\
\hline & & $\begin{array}{c}\text { Partition } \\
\text { wall }\end{array}$ & none \\
\hline
\end{tabular}

Note: 'none' means that this item is not specified in either standards.

\subsection{Optimization methods and settings}

\subsubsection{Genetic Algorithm}

Genetic algorithm (GA) is an adaptive global optimization search algorithm formed by simulating the genetic and evolutionary processes of living things in the natural environment. It borrows the perspective of biogenetics, and through the mechanisms of natural selection, inheritance, and mutation, it achieves the improvement of individual adaptability. First proposed by John Holland in the mid-1970s in the University of Michigan, they have been successfully employed in many fields of study, including the architecture and construction field, and the energy efficiency of buildings and their components [22]. 
NSGA stands for Non-dominated Sorting Genetic Algorithm and NSGA-II is an elitist version of NSGA. Being a genetic algorithm, NSGA-II shares the same overall GA dynamic. There is a main loop that iterates generation by generation, there is fitness evaluation and there are selection, crossover and mutation operators. However, these operators are especially designed to work in multi-objective problems.

In comparison with the normal GA, NSGA-II has a series of modifications to its operators, most importantly its selection operator. NSGA-II does not directly use the fitness values to select the best individuals and, consequently, the individuals who will be used for reproduction. As its name suggests, NSGA-II uses a Non-dominated Sorting (NDS) algorithm to assess the position of all solutions in the objective space and to sort them according to Pareto fronts. Additionally, NSGA-II uses a special diversity preservation algorithm called Crowding Distance (CD). NSGA-II selects its best individuals according to a combination of the values obtained with the NDS and CD algorithms [23].

\subsubsection{Multi-objective optimization method}

In the current work, an integrated method for building design is proposed to obtain detailed information about the green roofs through a multi-objective genetic algorithm. A multi-objective search was subsequently conducted with the goal of minimizing the energy required for heating and cooling of open-space office buildings by changing some green roof design variables. These variables are roof insulation thickness, plant substrate (soil) thickness, plant parameters, etc. In five climates, the above-mentioned typical building model was selected for optimization analysis. The search is performed by implementing the NSGA-II algorithm, which can exchange information with EnergyPlus simulation tools.

Multi-objective optimization differs from a single objective in that in order to compare two solutions and determine which is the best solution. Its performance needs to be considered in multiple objective, not just one.

The objective of this article is to calculate building heating and cooling energy. For the case study, these objectives should be minimized. The overall characteristics of the analyzed building are described in 2.2. Except that the roof was modified to a green roof, the rest of the structure and interior conditions are consistent with the reference building.

\subsubsection{Optimization criteria}

The optimisation was performed by changing the following parameters:

1. Insulation thickness of green roofs(Ti). The roof structure is reinforced concrete and XPS insulation from bottom to top. Considering that the standard stipulates different heat transfer coefficient limits of roofs in different climatic zones, the variation range of thermal insulation layer in different climatic zones is not consistent. See Table 2 for details. And the optimized step is $5 \mathrm{~mm}$;

2. Soil thickness(Ts). Green roofs are generally divided into two categories, including dense and extensive green roofs [24]. Of these two types, extensive green roofs are the most common in the world due to weight restrictions, costs, and maintenance of the building. Therefore, extensive green roofs were selected to optimize the energy performance of their buildings. Soil thickness varies from $60-160 \mathrm{~mm}$ with an optimized step of $5 \mathrm{~mm}$.

3. Plant parameters. In EnergyPlus, the most important plant parameters are height of plant(H), leaf area index (LAI), leaf reflectance (LR), and leaf emissivity (LE). The above parameters are selected as plant optimization parameters in this paper, see Table 3.

Table 2. Variable domains for XPS thickness.

\begin{tabular}{cc}
\hline Climate zones & Variable domains $(\mathbf{m m})$ \\
\hline Severe cold zone & $10-140$ \\
\hline Cold zone & $10-90$ \\
\hline $\begin{array}{c}\text { Hot summer and cold } \\
\text { winter zone }\end{array}$ & $10-80$ \\
\hline $\begin{array}{c}\text { Hot summer and warm } \\
\text { winter zone }\end{array}$ & $10-40$ \\
\hline Moderate climate zone & $10-40$ \\
\hline
\end{tabular}

Table 3. Variable domains for plant parameters.

\begin{tabular}{ccc}
\hline Plant parameters & Variable domains & Step \\
\hline Height of plant & $0.1-1.0 \mathrm{~m}$ & $0.1 \mathrm{~m}$ \\
\hline Leaf area index (LAI) & $0.5-5$ & 0.5 \\
\hline Leaf reflectance (LR) & $0.1-0.4$ & 0.1 \\
\hline Leaf emissivity (LE) & $0.8-1.0$ & 0.1 \\
\hline
\end{tabular}

\subsubsection{GA input}

For all simulations, NSGA-II explored 50 generations with 30 individuals in each generation. The overall genetic inputs are reported in Table 4.

Table 4. Genetic inputs.

\begin{tabular}{cc}
\hline Maximum generations $(\mathrm{G})$ & 50 \\
\hline Population size $(\mathrm{NP})$ & 30 \\
\hline Crossover rate $\left(\mathrm{P}_{\mathrm{c}}\right)$ & 1.0 \\
\hline End condition & $\begin{array}{c}\text { End after 50 generations or no } \\
\text { Pareto optimal value within the } \\
\text { latest 7 generations }\end{array}$ \\
\hline
\end{tabular}

\section{Results}

The results are divided into two sections for ease of comparison. In the first, the energy of green roofs (GRB) is compared with that of the reference roofs $(\mathrm{RB})$. And then optimal parameters of green roofs are presented. The calculations reflect the energy demand without consideration of the energy system efficiencies so that focus is on the roofs behavior. 


\subsection{Energy performance of green roofs with optimal properties comparing with reference roofs}

Fig. 2 presents the heating, cooling, and total energy demand for each roof type, as well as the energy-saving rate of green roofs (compared with reference roofs).

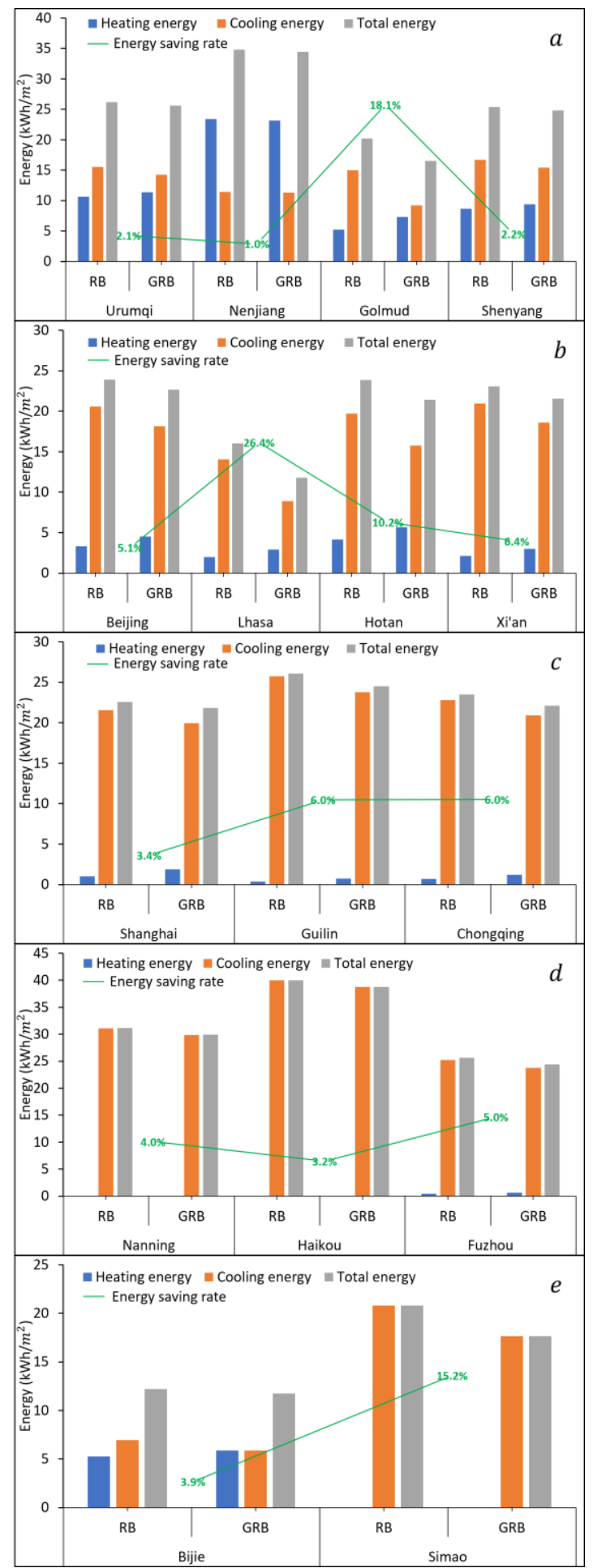

Fig. 2. Energy Consumption and energy-saving rate in five climatic zone (a, severe cold zone; b, cold zone; c, hot summer and cold winter zone; $d$, hot summer and warm winter zone; e, moderate climate zone.)
As shown in Fig. 2, the energy-saving rate of green roofs is between $1.0 \%$ and $26.4 \%$. Except for the Nenjiang, the heating energy consumption of green roofs has almost increased. The heating energy consumption of Guilin in the hot summer and cold winter zone increased by $113.2 \%$, while the heating energy consumption of Nenjiang decreased by $1.1 \%$. This phenomenon can be attributed to the fact that the main energy consumption of Nenjiang is for heating, which is twice than that of cooling energy, so the roof structure is mainly for thermal insulation. Compared with heating energy consumption, the cooling energy consumption of green roofs has been reduced in all cities, indicating that green roofs are more beneficial for reducing cooling energy consumption. It attributed to the particularity of office buildings, which contains a large amount of heat gain from equipment and personnel activities. Also, extensive use of transparent envelope may lead to a large number of solar heat gain, so most of the office buildings are dominated by cooling energy consumption.

From the perspective of the energy performance of the climatic zone, the annual energy-saving rate of Urumqi in the severe cold zone is $2.1 \%, 1.0 \%$ in Nenjiang, 2.2\% in Shenyang, and the energy-saving rate is not high. The phenomenon is similar in the cold zone: Beijing and Xi'an have annual energy-saving rates of $5.1 \%$ and $6.4 \%$, Hotan is $10.2 \%$, and Lhasa is as high as $26.4 \%$. And moderate zone: Bijie is $3.9 \%$, Simao is up to $15.2 \%$. Comparing the energy-saving rate with the distribution of the annual total solar radiation value, it is found that under the same climatic conditions, the annual energy-saving rate has a high correlation with the annual total solar radiation value, that is, a city with a larger total annual solar radiation value, the higher the annual energy-saving rate is. In hot summer and cold winter zone, such as Shanghai, Chongqing, Guilin, where the total annual solar radiation value is low, the energysaving rate is between $3.4-6.0 \%$. Similarly, in hot summer and warm winter zone, such as Nanning, Haikou, and Fuzhou, the energy-saving rate is between 3.2-5.0\%.

Therefore, it can be considered that the energysaving performance of green roofs is not only related to the climate zone in which it is located, but also to the total annual solar radiation value at its location. So, it is not sufficient to evaluate the benefits of green roofs only from the climate zone where the building is located, which is different from the existing research.

\subsection{Optimal parameters of green roofs in four zones based on the energy performance}

According to the simulation results, the performance of green roofs is different in each climate zone. Table 5 shows the roof structures and plant parameters with the best energy performance of green roofs in typical cities in several climatic zone. It can be seen from the table that the optimal thickness of the insulation layer is 140 $\mathrm{mm}$ in Nenjiang. This is because the Nenjiang is near the northernmost point of China, and the heating energy 
accounts for most of the annual energy consumption of buildings.

Therefore, green roofs are mainly for thermal insulation. In other cities, the use of green roofs has reduced the thickness of insulation to varying degrees. It is worth noting that it also increases its energy-saving performance. For example, in hot summer and cold winter zone and hot summer and warm winter zone, the optimal insulation thickness is $10 \mathrm{~mm}$, indicating that thinner insulation layers are more conducive to green roofs and improve their energy-saving performance.

Table 5. Optimal properties of green roofs in different cities in different zones.

\section{$\begin{array}{lllllll}\text { City } & \text { H } / \mathrm{m} & \text { LE } & \text { LR } & \text { LAI } & \text { Ts } / \mathbf{m m} & \text { Ti } / \mathbf{m m}\end{array}$}

\begin{tabular}{ccccccc}
\hline Urumqi & 0.3 & 1.0 & 0.4 & 5.0 & 105 & 60 \\
\hline Nenjiang & 0.5 & 0.9 & 0.1 & 5.0 & 105 & 140 \\
\hline Golmud & 0.2 & 0.8 & 0.1 & 5.0 & 105 & 10 \\
\hline Shenyang & 0.5 & 1.0 & 0.4 & 5.0 & 105 & 50 \\
\hline Beijing & 0.2 & 1.0 & 0.4 & 5.0 & 105 & 15 \\
\hline Lhasa & 0.8 & 0.9 & 0.1 & 5.0 & 105 & 10 \\
\hline Hetian & 0.1 & 0.8 & 0.1 & 5.0 & 105 & 10 \\
\hline Xi'an & 0.2 & 1.0 & 0.3 & 5.0 & 105 & 15 \\
\hline Shanghai & 0.4 & 1.0 & 0.1 & 4.5 & 120 & 10 \\
\hline Guilin & 0.2 & 1.0 & 0.3 & 5.0 & 120 & 10 \\
\hline Chongqing & 0.2 & 1.0 & 0.3 & 4.0 & 105 & 10 \\
\hline Nanning & 0.5 & 1.0 & 0.4 & 5.0 & 90 & 10 \\
\hline Haikou & 0.1 & 1.0 & 0.4 & 5.0 & 90 & 10 \\
\hline Fuzhou & 0.3 & 1.0 & 0.1 & 5.0 & 90 & 10 \\
\hline Bijie & 0.6 & 0.9 & 0.3 & 5.0 & 120 & 15 \\
\hline Simao & 0.6 & 1.0 & 0.3 & 5.0 & 60 & 10 \\
\hline
\end{tabular}

In terms of planting substrates, optimal soil thickness is only $60 \mathrm{~mm}$ in Simao. Except it, most soil thicknesses of $90-120 \mathrm{~mm}$ are considered suitable, with a thickness of $105 \mathrm{~mm}$ being most suitable in severe cold and cold zone. In terms of plant parameters, it seems that a larger leaf area index is good for green roofs in most cities, but the best leaf area indexes for Shanghai and Chongqing are 4.5 and 4.0, respectively. Also, their energy characteristics show similarities and differences in leaf emission and reflection coefficients. Finally, it is worth emphasizing that the height of plants in the previous literature has a great impact on the energy performance of green roofs, which is also reflected in this optimization. It is interesting that higher plants are not more beneficial to their energy performance. And even the optimal plant heights vary greatly in the same climatic zone. For example, Hotan and Lhasa are both cold regions, but their optimal plant heights are 0.1 and $0.8 \mathrm{~m}$, respectively.

In addition, it has been found that green roofs with certain combinations of plant parameters and roof structure may have a negative impact on their energy performance. For example, when Golmud increased its insulation thickness from $10 \mathrm{~mm}$ to $125 \mathrm{~mm}$ and its leaf area index decreased to 1 , its total energy consumption increased from 16.5 to $21.0 \mathrm{kWh} / \mathrm{m}^{2}$, which was an increase of $3.8 \%$ compared to the reference building. Therefore, the study of the structural and plant parameters of green roofs in different cities is very important to determine their energy saving performance.

Finally, we suggest that the energy performance of green roofs cannot be roughly estimated according to the climatic zone, which is slightly different from the existing research results. Therefore, the relationship between the energy performance of green roofs and the climate needs to be further confirmed.

\section{Conclusion}

In this paper, based on genetic algorithms, the roofing structure and plant parameters are optimized for the energy performance of office buildings with green roofs in representative cities in five climatic zones in China. The following conclusions can be drawn from this study.

The energy-saving performance of green roofs is not only related to the climate zone in which it is located, but also to the total annual solar radiation value of the location. Therefore, simply evaluating the energy performance from the climate zone where the building is located may underestimate the benefits of green roofs, which is different from existing research. In addition, after a comparative study of different climatic zones and cities, it was found that not all green roofs have good energy performance, and unoptimized green roofs have the risk of increasing building energy consumption. However, the optimized green roof's energy performance in all climate zones and cities has been improved compared to reference buildings, and the energy saving rate is between $1.0 \%$ and $26.4 \%$.

In terms of the roof structure, the better insulation performance of the roof, the better energy performance of green roofs in cities where heating is the most important. In areas where cooling is the main considered, the thinner the insulation layer is, the better the green roof $\mathrm{s}$ will perform its energy saving performance. In terms of plant parameters, a larger leaf area index is beneficial to green roofs in all regions to improve their energy efficiency, while other parameters, especially the height of plants, need to be further confirmed according to each city.

In summary, we found that optimized green roofs based on building simulation combined with genetic algorithm (GA-II) optimization calculations can reduce building energy consumption in most cities. This method is worthy of being adopted by researchers in more cities to extend the applicability of green roofs to other parts of China and even other countries.

\section{References}

1. L. Pérez, J. Ortiz, J. Coronel, I. Maestre, Energy Build, 43 (2011)

2. H. Goudarzi, A. Mostafaeipour, Renew. Sustain. Energy Rev., 68 (2017)

3. K.L. Getter, D. Bradley Rowe, B.M. Cregg, Urban For. Urban Gree., 8 (2009)

4. R.A. Francis, J. Lorimer, J. Environ. Manage., 92 (2011) 
5. M. Zinzi, S. Agnoli, Energy Build., 55 (2012)

6. D.J. Sailor, T.B. Ellery, M. Gibson,J. Build.Phys., 35 (2011)

7. D.J. Sailor, A green roof model for building energy simulation programs, Energy Build., 40 (2008)

8. J.T. Lundholm, B.M. Weddle, J.S. MacIvor, Energy Build., 84 (2014)

9. I. Jaffal, S. Ouldboukhitine, R. Belarbi, Renew. Energy, 43 (2012)

10. C.Y. Jim, L.L.H. Peng, Landscape Ecol. Eng. , 8 (2012)

11. C.Y. Jim, S.W. Tsang, Build. Environ., 46 (2011)

12. L. Jiang, M. Tang, Energy Build., 156 (2017)

13. Y. He, H. Yu, N. Dong, H. Ye, Energy Build., 127 (2016)

14. P. Bevilacqua, Domenico Mazzeo, Natale Arcuri, Build. Environ., 131(2018)

15. P.L. Roche, U. Berardi, Energy Build., 82 (2014)

16. J. Ran, M. Tang, Sustain. Cities Soc., 38 (2018)

17. J. Ran, M. Tang, Energy Procedia, 141 (2017)

18. C. Zeng, X. Bai, L. Sun, Y. Zhang, Y. Yuan, Energy Build., 150 (2017)

19. MOHURD, China Building Industry Press(GB 50178), Beijing, (1993)

20. MOHURD, China Building Industry Press(GB 50189), Beijing, (2015)

21. MOHURD, China Building Industry Press(GB/T 51350), Beijing, (2019)

22. S. Attia, M. Hamdy, W. O'Brien, S. Carlucci, Energy Build., 60 (2013)

23. T. Echenagucia, A. Capozzoli, Y. Cascone, M. Sassone, Appl. Energ., 154 (2015)

24. K. Vijayaraghavan, Renew. Sustain. Energy Rev., 57 (2016) 